\title{
Impact of Micronaire Reading on Nep Formation During Cotton Yarn Processing
}

\author{
Beheary, M.G.I ${ }^{1}$; El-Sayed, M.A.M. ${ }^{2}$; Ibrahim, I.A.E. ${ }^{1}$ and Badwy, I.A.G.E. ${ }^{3}$ \\ 1 Faculty of Agriculture (Saba Basha), Plant Production Dept., Alex. Uni., Egypt \\ ${ }^{2}$ Cotton Research Institute, Agriculture Research Center, Giza, Egypt \\ ${ }^{3}$ Cotton Arbitration and Testing General Organization, (CATGO), Alexandria, Egypt
}

Corresponding author: Beheary, M.G., e-mail: mashhout05@yahoo.com

\begin{abstract}
This investigation was carried out at Al-Amria Spinning and Weaving Company to study the impact of Micronaire reading on neps formation during cotton yarn processing. Four micronaire readings i.e., (4.49 for Giza 86, 4.27 for Greece upland cotton, 4.23 for Giza 80 and 4.08 Giza 88 ) and four yarn counts i.e., (50, 80 Ne for combed yarns and 24, 30 for carded yarn). The obtained results could be summarized as follow:

- The highest fiber length (UHML), uniformity index and fiber elongation were recorded for Giza 88 was the lowest micronaire reading (4.08).

- The lowest number of neps was associated with the intermediate micronaire value 4.23 and card sliver stages. While, the lowest micronaire reading 4.08 of Giza 88 recorded the lowest number of neps at yarn stage.

- The increase in yarn strength, yarn evenness CV\%, thin, thick and number of neps were a compared with the micronaire reading increase for Giza 86 and Giza 88.

- The highest yarn strength with the lowest evenness CV\% and imperfections i.e., thin, thick places and number of neps were attained using the lowest yarn count.

- Most fiber and yarn properties of the studied four cotton varieties were negatively correlated.

Key words: Micronaire; Nep formation; Yarn processing; HVI; Carded; Combed; sliver
\end{abstract}

\section{INTRODUCTION}

One of the most important fiber parameters that cause a decrease in cotton quality is neps; a nep can be defined as "a small knot of entangled fibers consisting entirely of fibers (i.e. a fiber neps) or of foreign matter (i.e. a seedcoat fragment) entangled with fibers, Layton and Buchanan (1999). Hebert et al. (1988), reported that cotton variety is believed to be responsible for $30 \%$ of the problem, growing area $30 \%$, and the remaining $40 \%$ is unknown. Neps can be caused by environmental factors during growth, processing and are inherent to particular varieties. Also, harvesting increases the number of neps. Mechanical harvesting gives up to $30 \%$ more neps than hand picking. Later each operation, drying, cleaning, ginning and carding, again increase the number of neps. Gonca and Erhan (2006), stated that there is a direct correlation between the quality of raw materials and the end products. The lower quality of cotton fibers means lower quality of yarn produced from such a raw cottons. Neps are formed during fiber development, harvesting, ginning, and cleaning; especially if immature fibers or broken fibers are created during ginning and cleaning, Hebert et al. (1988) and Mangialardi (1986). Likewise, Yanky and Quad (1995), stated that at the same value of micronaire index, cotton can have different levels of immature fiber content and undyed neps due to dead fibers, which is the reason for non-uniform dyeing of fabrics. Van der Sluijs and Hunter (1999), reported in a study where Micronaire emerged as the most significant fiber 
property in terms of determining nep levels and nep size. Also reported that the number of neps per gram decreased as micronaire, length uniformity ratio, strength, and span length increased. Joseph and Montalvo (2005), stated that micronaire is an indicator of air permeability. It is regarded as an indication of both fineness (linear density) and maturity (degree of cell-wall development). For a given type of cotton, a relatively low micronaire has been used as a predictor of problems in processing, but a low micronaire may also indicate fine fibers with adequate maturity. similarly, growers may be discounted for high micronaire when, in fact, the fibers have adequate fineness and good maturity, because high micronaire fibers are normally coarse, which is undesirable from the point of view of spinning and yarn evenness. Altintas et al. (2007), mentioned that cotton containing dead and/or immature fibers is a major concern in the dyeing and finishing of textile products. in an un-dyed state, entangled fiber clusters are generally classified as neps. It is only after the application of dye, when some neps remain un-dyed, that the more specific classification of "white speck" is used. The high volume instrument (HVI) fiber property measurement system is important in marketing and general quality assessment of the cotton crop. Bednarz et al. (2002) and Bange et al. (2010), mentioned that precise identification of cotton crop maturity is important for maintaining yields and fiber quality when preparing for harvest. Delayed harvest increases the chance of fiber weathering and harvesting more leaf trash, while prematurely harvesting cotton with significant amounts of immature bolls may lower lint yield and micronaire (a measure of fiber fineness and maturity), and increase neps (fiber entanglements). Patricia and Bugao (2010), indicated that seed coat fragments (SCF) can produce neps that can cause spinning problems and fabric defects, which ultimately cause losses to the cotton industry. Fiber to yarn conversion process has been affected by several factors which include properties of raw material, level of technology, machinery and skill of machine operators. Yarn imperfection (neps, thick and thin places) on the other hand is important yarn parameters which affects yarn and fabric processing, and quality parameter, Ochola et al. (2012).

The aim of this study was to clarify the effect of the micronaire reading on formation nep ability during the yarn production stages.

\section{MATERIALS AND METHODS}

Four representative lot sample of $100 \mathrm{~kg}$ each having different micronaire readings i.e., $4.08,4.49,4.23$ and 4.27 belonged to four cotton varieties i.e., Giza 88, Giza 86, Giza 80 and Upland (Greece cotton), respectively were used in this investigation which was carried out in Al- Amria Spinning and Weaving Company, Alexandria, Egypt.

Three representative laboratory samples (about $200 \mathrm{~g}$ each) were withdrawn from each lot sample as replicates to determine fiber properties and nep count.

\section{Studied Characters}

Fiber and yarn properties tests were carried out under the standard conditions of $21 \pm 2{ }^{\circ} \mathrm{C}$ temperature and $65 \pm 2 \%$ relative humidity in Al-Amria Company. 


\section{H.V.I. fiber properties}

The fiber physical properties of the cotton samples were tested by the High Volume Instrument (H.V.I.) spectrum 1 according to American Stander for Testing Materials (ASTM).

\section{Nep count}

The nep count per gram of the cotton fibers was determined through the different stages of yarn processing i.e., blow room, card sliver, combing sliver using Neptometer instrument according to ASTM.

\section{Yarn properties}

The rest of the lot sample of each cotton variety $(100 \mathrm{Kg})$ was processed through blow room line, shute feed, carding machine, draw frame, combing, roving and ring spinning. The Egyptian cotton varieties Giza 88 and Giza 86 were manufactured to combed yarns $(50$ and $80 \mathrm{Ne})$ on conventional ring spinning frame at constant twist multiplier " 4.3 ". Whereas, the cotton varieties Giza 80 and the Upland cotton were spun to carded yarns (24 and $30 \mathrm{Ne}$ ) on the same ring frame.

Yarn strength and elongation: The spun yarns were tested for the following parameters: single yarn strength (cN/tex), elongation at break (\%) using Statimat ME Instrument.

Yarn evenness and imperfections: These involved measuring the yarn evenness CV\%, number of thick and thin places and neps per 1000 meters of the yarn using USTER III equipment in accordance with the procedures of the American Stander for Testing Materials (ASTM standard, 1997).

\section{Statistical procedures}

The completely randomized design with three replications was used to outline this work. The attained data was statistically analyzed as a factorial experiment according to the procedure of Snedecor and Cochran (1967) using Co-state program version 3.6. The least significant difference (L.S.D.) was calculated to compare treatment means at 0.05 level of probability.

\section{RESULTS AND DISCUSSION}

\section{H.V.I. fiber properties}

Regarding data in Table (1), it could be noticed that there were significant differences in all studied H.V.I. fiber properties due to the micronair value of cotton variety. The highest mean value of UHML (upper half mean length) $(35.18 \mathrm{~mm})$, uniformity index $(87.24 \%)$, fiber bundle strength $(45.72$ $\mathrm{g} / \mathrm{tex})$, fiber elongation $(7 \%)$ and the lowest short fiber content $(6.04 \%)$ were recorded for the Egyptian cotton variety Giza 88, with the lowest micronaire reading (4.08). Likewise, the highest mean value for fiber maturity $(87.8 \%)$ realized from Giza 86 the highest micronaire reading, 4.49. On the other side, the lowest mean value of UHML, Uniformity index, fiber maturity, fiber strength, elongation \% and Rd \% were attained from Giza 80, with micronaire reading (4.23). 
It could be concluded that the fiber UHML, length uniformity, maturity, strength, and elongation proportionally decreased as the micronaire reading increased and vice versa.

These results are in agreement with Ibrahim (2013) who attributed that the best genetic structure of the extra-long staple cottons viz. Giza 88 which is characterized to the best fiber properties especially fiber length, bundle strength, uniformity ratio, fineness and the lowest short fiber content \%.

Table (1). Mean values of HVI fiber properties as affected by Micronaire value (cotton variety)

\begin{tabular}{c|cccccc}
\hline Parameters & UHML & UI & SF & Maturity & Mic & Str \\
Variety (Mic.) & & & & & & \\
\hline Giza $86(4.49)$ & $32.08 \mathrm{~b}$ & $86.12 \mathrm{~b}$ & $6.08 \mathrm{~b}$ & $87.8 \mathrm{a}$ & $4.52 \mathrm{a}$ & $43.42 \mathrm{~b}$ \\
Giza $80(4.23)$ & $30.02 \mathrm{c}$ & $83.14 \mathrm{c}$ & $8.06 \mathrm{a}$ & $83 \mathrm{c}$ & $4.26 \mathrm{ab}$ & $34.98 \mathrm{c}$ \\
Upland (4.27) & $29.2 \mathrm{~d}$ & $83.24 \mathrm{c}$ & $8.22 \mathrm{a}$ & $86.8 \mathrm{ab}$ & $4.26 \mathrm{ab}$ & $29.88 \mathrm{~d}$ \\
Giza 88 (4.08) & $35.18 \mathrm{a}$ & $87.24 \mathrm{a}$ & $6.04 \mathrm{~b}$ & $85.2 \mathrm{~b}$ & $4.08 \mathrm{~b}$ & $45.72 \mathrm{a}$ \\
L.S.D 0.05 & 0.763 & 1.03 & 0.28 & 2.130 & 0.22 & 1.111 \\
\hline
\end{tabular}

Table (1). Continuous

\begin{tabular}{c|ccccc}
\hline & Elg & Rd &.$+\mathrm{b}$ & TrCnt & $\operatorname{TrAr}$ \\
\hline Variety (Mic.) & & & & & \\
\hline Giza 86 (4.49) & $6.0 \mathrm{~b}$ & $76.16 \mathrm{a}$ & $8.38 \mathrm{~d}$ & $46.6 \mathrm{~b}$ & $0.7 \mathrm{~b}$ \\
Giza 80 (4.23) & $5.4 \mathrm{c}$ & $64.52 \mathrm{~d}$ & $12.32 \mathrm{a}$ & $114.8 \mathrm{a}$ & $1.24 \mathrm{a}$ \\
Upland (4.27) & $5.38 \mathrm{c}$ & $69.46 \mathrm{~b}$ & $10.42 \mathrm{c}$ & $26.2 \mathrm{c}$ & $0.36 \mathrm{c}$ \\
Giza 88 (4.08) & $7.0 \mathrm{a}$ & $67.64 \mathrm{c}$ & $11.36 \mathrm{~b}$ & $56.0 \mathrm{~b}$ & $0.8 \mathrm{~b}$ \\
L.S.D 0.05 & 0.386 & 1.484 & 0.428 & 10.324 & 0.172 \\
\hline
\end{tabular}

UHML: Upper half mean length, UI: Uniformity index, SF: Short fiber, Mic.: Micronaire, Str.: Strength, Elg.: Elongation, Rd: Reflectance degree, +b: Brightness, TrCnt: Trash count and TrAr: Trash area

Mean values designated by the same letter in each column are not significantly different according to L.S.D. 0.05 values.

\section{Nep count}

Data shown in Table (2) revealed significant differences in nep count of raw cotton, carded sliver, combing sliver and yarn due to the cotton variety or Micronaire reading. The highest mean values of nep count $(220.6,65,59.6$ and 146) were gained from the upland cotton (4.27 Mic.) in stage of raw cotton, Giza 86, (4.49 Mic.) and Giza 88 (4.08 Mic.) in carded sliver, and yarn of upland (mic. $4.27)$, respectively. On the contrary, the lowest mean values of nep count 
(21.83) was recorded by Giza 88 with the lowest micronaire reading at yarn stage.

\section{Combed yarn properties}

\subsection{Effect of cotton variety (Micronaire value)}

With regard to data in Table (3), significant differences were found in the studied combed yarn properties due to cotton variety (micronaire reading), except yarn strength, elongation and hairiness. The yarn evenness CV\%, thin places, thick places and number of neps were statistically increased as the micronaire value increased from 4.08 to 4.49 .

Table (2). Mean values of the number of neps in raw cotton, carde sliver, combed sliver and yarn as affected by Micronaiı value (cotton variety)

\begin{tabular}{c|cccc}
\hline Parameters & $\begin{array}{c}\text { Raw } \\
\text { cotton } \\
(\mathrm{g})\end{array}$ & $\begin{array}{c}\text { Card } \\
\text { sliver } \\
(\mathrm{g})\end{array}$ & $\begin{array}{c}\text { combing sliver } \\
(\mathrm{g})\end{array}$ & $\begin{array}{c}\text { Yarn } \\
(1000 \mathrm{~m})\end{array}$ \\
\hline Variety (Mic.) & $74.66 \mathrm{~b}$ & $59.6 \mathrm{a}$ & $37.6 \mathrm{a}$ & $21.83 \mathrm{c}$ \\
Giza 88 (4.08) & $73.83 \mathrm{~b}$ & $65.0 \mathrm{a}$ & $30.3 \mathrm{a}$ & $95.16 \mathrm{~b}$ \\
Giza 86 (4.49) & $73.00 \mathrm{~b}$ & $12.6 \mathrm{~b}$ & - & $84.83 \mathrm{~b}$ \\
Giza 80 (4.23) & $220.60 \mathrm{a}$ & $14.6 \mathrm{~b}$ & - & $146.00 \mathrm{a}$ \\
Upland (4.27) & 9.60 & 19.72 & $\mathrm{NS}$ & 35.01 \\
L.S.D 0.05 & & & &
\end{tabular}

NS: Not significant

Mean values designated by the same letter in each column are not significantly different according to L.S.D. 0.05 values.

Table (3). Mean values of combed yarn properties as affected by Micronaire value (cotton variety) and yarn counts

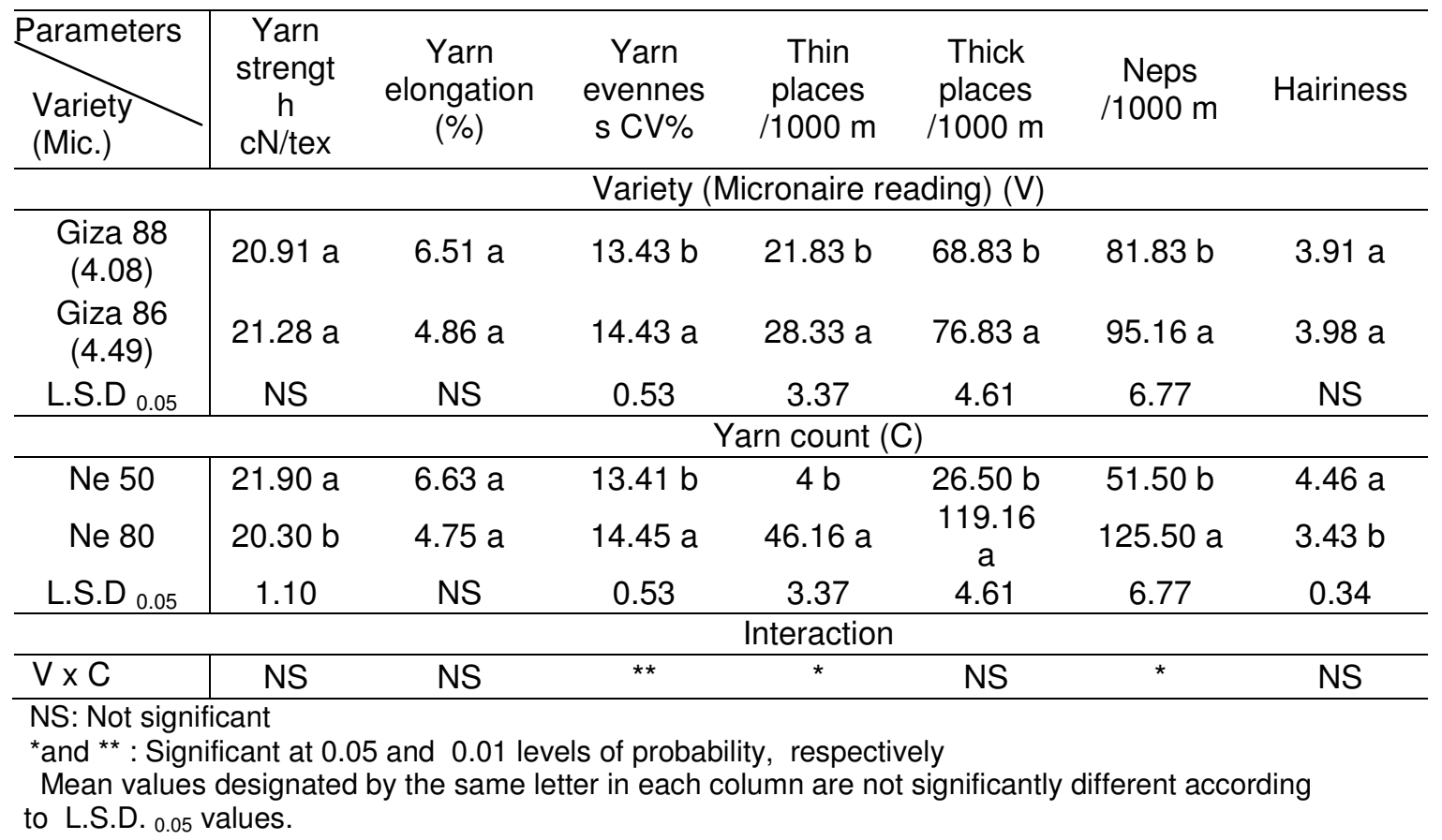




\subsection{Effect of yarn count}

All studied combed yarn characters were significantly influenced by the yarn count except, yarn elongation as shown in Table (3). The single yarn strength and hairiness were significantly decreased meanwhile; yarn evenness CV\%, thin places, thick places and nep count/1000 $\mathrm{m}$ of yarn were significantly increased as the yarn count increased from 50 to $80 \mathrm{Ne}$ in both studied cotton varieties, Giza 88 and Giza 86.

These result were in agreement with those obtained by Ibrahim (2006) who stated that increasing yarn count (English system) decreased yarn strength because the yarn becoming finer and that led to decrease in number of fiber in cross-section and vice versa. In addition, the number of imperfections (Yarn evenness CV\%, thin, thick places and number of neps) became more which was visible and easily to determine and vice-versa.

\subsection{The interaction between cotton variety and yarn count $(\mathrm{V} \times \mathrm{C})$}

The interactions between cotton variety (Mic. Value) and yarn count ( $\mathrm{X}$ C) were significant in yarn evenness $\mathrm{CV} \%$, thin places and number of neps/1000m only. The lowest mean values for these traits $(13.3,13.5,13.5,3,5$ 49.3 and 53.6), respectively were attained from Giza 86 by using the highest micronaire value, (4.49) spun at the lowest yarn count (50 $\mathrm{Ne})$ and vice versa, as shown in Table (4).

Giza 88 variety spun at 80 count recorded the highest number of yarn evenness CV\%, thin places and neps $/ 1000 \mathrm{~m}$ of the yarn.

Generally, yarn evenness CV\%, the number of thin places and neps/1000 m were proportionally increased by increasing yarn count.

\section{Table (4).The interaction between Micronaire value (cotton variety) and yarn count ( $V \times C$ ) for yarn evenness, thin places and fiber neps}

\begin{tabular}{c|c|ccc}
\hline \multicolumn{2}{c}{ Treatments } & \multicolumn{3}{c}{ Parameter } \\
\hline $\begin{array}{c}\text { Variety (Mic.) } \\
\text { (V) }\end{array}$ & $\begin{array}{c}\text { Count } \\
\text { (C ) }\end{array}$ & $\begin{array}{c}\text { Yarn } \\
\text { evenness } \\
\text { CV\% }\end{array}$ & $\begin{array}{c}\text { Thin places } \\
1000 / \mathrm{m}\end{array}$ & $\begin{array}{c}\text { Neps } \\
1000 / \mathrm{m}\end{array}$ \\
\hline \multirow{2}{*}{ Giza 86 (4.49) } & Ne 50 & $13.3 \mathrm{~b}$ & $3.0 \mathrm{C}$ & $49.3 \mathrm{C}$ \\
& Ne 80 & $13.5 \mathrm{~b}$ & $40.6 \mathrm{~b}$ & $114.3 \mathrm{~b}$ \\
Giza 88 (4.08) & Ne 50 & $13.5 \mathrm{~b}$ & $5.0 \mathrm{C}$ & $53.6 \mathrm{C}$ \\
\multicolumn{2}{c}{ Ne 80 } & $15.3 \mathrm{a}$ & $51.6 \mathrm{a}$ & $136.6 \mathrm{a}$ \\
L.S.D 0.05 & 0.65 & 4.13 & 8.29 \\
\hline
\end{tabular}

Mean values designated by the same letter in each column are not significantly different according to L.S.D. 0.05 values

\section{Carded yarn properties}

\subsection{Effect of cotton variety (Micronaire value)}

Data in Table (5) indicated that as the micronaire reading increased from 4.23 to 4.27 the yarn strength and nep count/1000 m were significantly decreased and concerning the number of yarn imperfections i.e., (thin and thick places) and hairiness were increased. 


\subsection{Effect of yarn count:}

Following the same pattern the yarn strength, elongation and hairiness decreased and the number of yarn imperfections i.e., (yarn evenness CV\%, thin, thick and neps count) increased by increasing the yarn count from $24 \mathrm{Ne}$ to $30 \mathrm{Ne}$, as shown in Table (5).

Table (5). Mean values of carded yarn properties as affected by Micronaire value (cotton variety) and yarn count

\begin{tabular}{|c|c|c|c|c|c|c|c|}
\hline $\begin{array}{l}\text { Parameters } \\
\text { Variety } \\
\text { (Mic.) }\end{array}$ & $\begin{array}{l}\text { Yarn } \\
\text { strength } \\
\text { cN/tex }\end{array}$ & $\begin{array}{c}\text { Yarn } \\
\text { elongatio } \\
n(\%)\end{array}$ & $\begin{array}{c}\text { Yarn } \\
\text { evenness } \\
\text { CV\% }\end{array}$ & $\begin{array}{l}\text { Thin } \\
\text { places } \\
/ 1000 \mathrm{~m}\end{array}$ & $\begin{array}{c}\text { Thick } \\
\text { places } / 100 \\
0 \mathrm{~m}\end{array}$ & $\begin{array}{c}\text { Neps/ } \\
1000 \text { m }\end{array}$ & Hairiness \\
\hline \multicolumn{8}{|c|}{ Variety ( Micronaire reading) (V) } \\
\hline $\begin{array}{c}\text { Giza } 80 \\
(4.23)\end{array}$ & $15.41 \mathrm{a}$ & $6.33 \mathrm{a}$ & $14.15 \mathrm{a}$ & $4.33 \mathrm{~b}$ & $103 \mathrm{~b}$ & $146 a$ & $6.16 \mathrm{~b}$ \\
\hline $\begin{array}{l}\text { Upland } \\
(4.27)\end{array}$ & $14.55 \mathrm{~b}$ & $5.60 \mathrm{a}$ & $13.93 \mathrm{a}$ & $9.66 \mathrm{a}$ & $152 \mathrm{a}$ & $84.83 \mathrm{~b}$ & $6.63 \mathrm{a}$ \\
\hline L.S.D 0.05 & 0.41 & NS & NS & 2.63 & 5.08 & 3.39 & 0.35 \\
\hline \multicolumn{8}{|c|}{ Yarn count $(\mathrm{C})$} \\
\hline $\mathrm{Ne} 24$ & $15.85 \mathrm{a}$ & $6.63 \mathrm{a}$ & $13.10 \mathrm{~b}$ & $5.33 \mathrm{~b}$ & $122 b$ & $99.50 \mathrm{~b}$ & $6.61 \mathrm{a}$ \\
\hline $\mathrm{Ne} 30$ & $14.11 \mathrm{~b}$ & $5.3 \mathrm{~b}$ & $14.98 \mathrm{a}$ & $8.66 \mathrm{a}$ & $133 a$ & $131.33 \mathrm{a}$ & $6.18 \mathrm{~b}$ \\
\hline L.S.D 0.05 & 0.41 & 1.07 & 0.39 & 2.63 & 5.08 & 3.39 & 0.35 \\
\hline \multicolumn{8}{|c|}{ Interaction } \\
\hline $\mathrm{V} \times \mathrm{C}$ & NS & NS & * & NS & ** & ** & NS \\
\hline
\end{tabular}

\subsection{The interaction between cotton variety and yarn count ( $\mathrm{V} \times \mathrm{C})$}

The interaction between cotton variety (Mic. value) and yarn count ( $\mathrm{V} x$ C) had significant effects on yarn evenness CV\%, thick places and number of neps $/ 1000 \mathrm{~m}$. The lowest mean values for the number of thick places (83.3) and neps $(78.6 / 1000 \mathrm{~m})$ were associated with the lowest micronaire value (Mic. 4.23 ) and yarn count $(24 \mathrm{Ne})$. Conversly, the lowest CV \% resulted from high micronaire reading (4.27) and yarn count (24 Ne), as shown in Table (6).

\section{Association between HVI fiber properties and yarn characters}

The relationships between some yarn traits and H.V.I. fiber properties for the studied cotton varieties were investigated. Looking at Table (7), it could be noticed that there were highly negative correlation coefficients between fiber reflectance degree $(\mathrm{Rd} \%)(0.94,0.95,0.95$ and 0.95$)$ and each of yarn thin places, thick places, neps/1000 $\mathrm{m}$ and hairiness, respectively, for the cotton variety Giza 88, shown in Table (7).

As for Giza 86, the correlation coefficient of the yarn evenness CV\% as well as yarn imperfections thin places, thick places, and number of neps, followed the same trend and negatively associated with the fiber reflectance degree (RD\%), as shown in the same table.

With regard to Giza 80, micronaire value was negatively correlated with the yarn evenness $\mathrm{CV} \%$ and nep count $(-0.83$ and -0.86$)$, respectively. 
However, trash area in that variety was positively correlated with nep yarn (0.82). Meanwhile, in the upland cotton, the correlation coefficients were positive and significant between the fiber bundle strength and both of yarn evenness CV\% and nep count (0.89 and 0.85), respectively.

Table (6). The interaction between Micronaire value (cotton variety) and yarn count ( $\mathrm{V} \times \mathrm{C})$ for yarn evenness, thick places and fiber neps

\begin{tabular}{cc|ccc}
\hline \multicolumn{2}{c|}{ Treatments } & \multicolumn{3}{c}{ Parameter } \\
\hline $\begin{array}{c}\text { Cotton variety } \\
\text { (Mic.) }\end{array}$ & $\begin{array}{c}\text { Yarn } \\
\text { count } \\
\text { (V) }\end{array}$ & $\begin{array}{c}\text { Yarn } \\
\text { evenness } \\
\text { CV\% }\end{array}$ & $\begin{array}{c}\text { Thick places } \\
1000 / \mathrm{m}\end{array}$ & $\begin{array}{c}\text { Neps } \\
1000 / \mathrm{m}\end{array}$ \\
\hline Giza 80 & $\mathrm{Ne} 24$ & $13.4 \mathrm{~b}$ & $83.3 \mathrm{~d}$ & $78.6 \mathrm{~d}$ \\
(4.23) & $\mathrm{Ne} \mathrm{30}$ & $14.8 \mathrm{a}$ & $122.6 \mathrm{c}$ & $91.0 \mathrm{C}$ \\
Upland & $\mathrm{Ne} 24$ & $12.7 \mathrm{C}$ & $160.6 \mathrm{a}$ & $120.3 \mathrm{~b}$ \\
(4.27) & $\mathrm{Ne} \mathrm{30}$ & $15.1 \mathrm{a}$ & $143.3 \mathrm{~b}$ & $171.6 \mathrm{a}$ \\
& & $\mathbf{0 . 5}$ & $\mathbf{6 . 2}$ & $\mathbf{4 . 2}$ \\
\hline
\end{tabular}

Mean values designated by the same letter in each column are not significantly different according to L.S.D. 0.05 values.

Table (7). Correlation coefficients ( $r$ ) between some HVI fiber properties and yarn characters for Giza $88,86,80$ and upland cotton varieties

\begin{tabular}{|c|c|c|c|c|c|}
\hline \multirow{2}{*}{$\underbrace{\text { Cotton Variety }}_{\text {Yarn properties }}$} & \multirow{2}{*}{$\begin{array}{c}\text { Giza } 88 \\
\begin{array}{c}\mathrm{Rd} \\
\%\end{array}\end{array}$} & \multirow{2}{*}{$\begin{array}{c}\text { Giza } 86 \\
\begin{array}{c}\mathrm{Rd} \\
\%\end{array}\end{array}$} & \multicolumn{2}{|c|}{ Giza 80} & \multirow{2}{*}{$\begin{array}{c}\text { Upland cotton } \\
\begin{array}{c}\text { Strength } \\
(\mathrm{g} / \mathrm{tex})\end{array}\end{array}$} \\
\hline & & & $\begin{array}{l}\text { Micronaire } \\
\text { value }\end{array}$ & $\begin{array}{c}\text { Trash area } \\
(\%)\end{array}$ & \\
\hline Yarn strength (cN/ tex) & NS & NS & NS & NS & NS \\
\hline Yarn elongation (\%) & NS & NS & NS & NS & NS \\
\hline Yarn evenness CV \% & NS & $-0.87^{*}$ & -0.83 * & NS & 0.89 * \\
\hline Thin places/1000 m & $-0.94^{* *}$ & $-0.84^{*}$ & NS & NS & NS \\
\hline Thick places/1000 m & $-0.95 * *$ & $-0.83 *$ & NS & NS & NS \\
\hline Yarn neps /1000 m & $-0.95^{* *}$ & -0.86 * & -0.86 * & 0.82 * & 0.85 * \\
\hline Yarn hairiness & $0.95^{* *}$ & NS & NS & NS & NS \\
\hline
\end{tabular}

\section{References}

Altintas, P.Z., J. L. Simonton and M. G. Beruvides (2007). Pilot Study to examine the relationship between AFIS fiber properties and white speck occurrence. Journal of Cotton Science, 11(3);159-167.

American Stander for Testing Materials (ASTM), 1986 D: 1578-1967, D: 1425 \& $2256-1984$, D-3818 \& D- 4605. USA.

A.S.T.M., Standard (1997). American Society for Testing Material, Part 32 and 33, Philadelphia, Pa. U.S.A

Bange, M.P., R.L. Long, G.A. Constable and S.G. Gordon (2010). Minimizing immature fiber and neps in upland cotton. Agron. J. 102:781-789. 
Bednarz, C.W., D.W. Shurley and W.S. Anthony (2002). Losses in yield, quality, and profitability of cotton from improper harvest timing. Agron. J. 94:1004-1011.

Gonca, O. and K., Erhan (2006). Examination of the influence of selected fiber properties on yarn nippiness. Fibres \& Textiles in Eastern Europe vol. $14,(3): 57$

Hebert, J.J., E.K. Boylston and D.P. Thibodeaux (1988). Anatomy of a nep. Textile Research Journal, 58(7), 380-382

Ibrahim, I. A. E. (2006). Technological studies on some Egyptian cottovn varieties. Ph.D. Thesis, Fac. Agric., (Saba Basha), Alex. Univ., Egypt.

Ibrahim, I. A. E. (2013). Effect of cotton variety and lint grade on some fiber and yarn properties. Journal of Applied Sciences Research, 9(6): 4015-4020.

Joseph, G. and Jr. Montalvo (2005). Relationships between micronaire, fineness, and maturity. Part I. Fundamentals. The Journal of Cotton Science, 9:81-88

Layton, J.M. and R.D. Buchanan (1999). Neps in cotton lint. Textile Progress, Oxford, , 28(4), 50p

Mangialardi, G.J. Jr. (1986). Evaluation of nep formation in the cotton gin. Textile Res. J., 55:756-761.

Ochola, J., J. Kisato, L. Kinuthia, J. Mwasiagi and A. Waithaka (2012). Study on the influence of fiber properties on yarn imperfections in Ring Spun Yarns. Asian Journal of Textile; Vol. 2 Issue 3, p32.

Patricia Bel and Xu Bugao (2010). Seed-coat fragment fiber and fabric quality in world cottons. Beltwide Cotton Conference, New Orleans, Louisiana, January 4-7.

Snedecor, G.W. and W.G. Cochran (1967). Statistical Method, $6^{\text {th }}$ ed. lowa Stat Univ. Press, 593p.

Van der Sluijs, M.H.J. and L. Hunter (1999). Neps in cotton lint. Textile Progress, Vol. 28 No.4

Yanky, J.M. and M. Quad (1995). Application of single fiber cotton maturity,. Uster Solutions No. 2, September. 


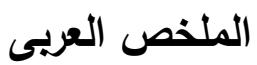

\section{تأثير قراءة الميكرونير على تكوين العقد خلال مراحل تصنيع خيوط القطن}

\section{مشحوت جناب اسماعيل بحيرى '، محمد عبد الرحمن السيد’ ، إبراهيم عباس السيد}

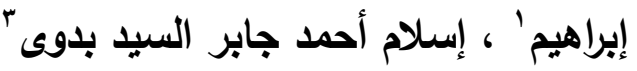

' كلية الزراعة سابا باشا - قسم الإنتاج النباتى (محاصيل)- جامعة الأسكندرية- مصر

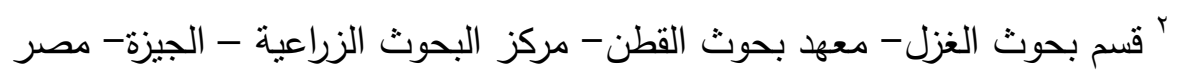

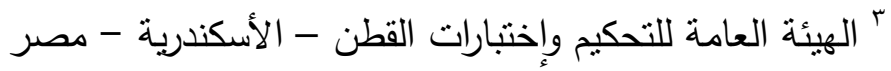

إقيمت هذة الدراسة بشركة العامرية للغزل والنسيج ـلدراسة تأثير قراءة الميكرونير على تكوين العقد خلال

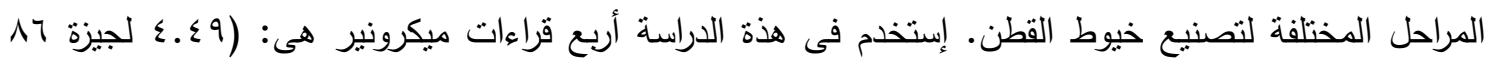

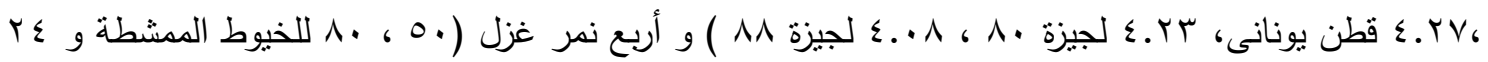

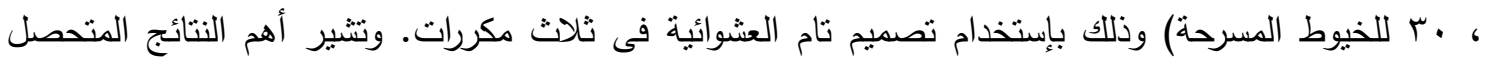
عليها ان :

أحسن طول وإنتظامية ومتانة وإستطالة للألياف سجلت لصنف جيزة ^^ (أقل قراءة ميكرونير ^ •..ء).

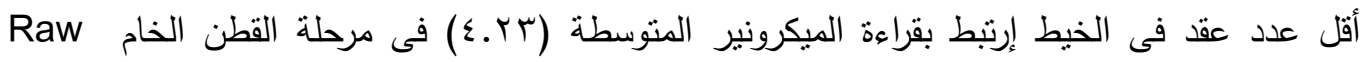

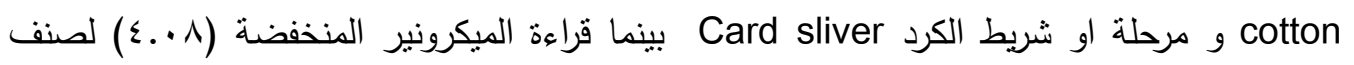
جيزة 1^ سجلت اقل عدد من العقد فى مرحلة الخيط. حدثت زيادة فى كل من متانة الخيط وعدم إنتظاميتة وعدد المناطق الرفيعة والسميكة والعقد بزيادة قراءة

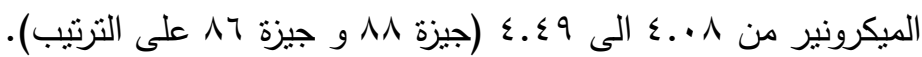

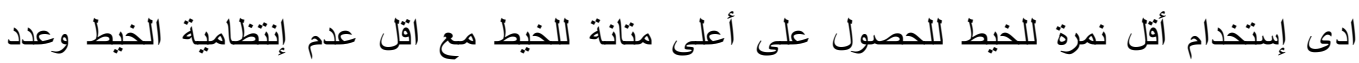

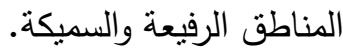
كانت معظم علاقات الإرنباط Correlation بين صفات الألياف وصفات الخيط الناتجة من أصناف القطن الأربعة سالبة (عكسية). 